\title{
Soil Maize Cultivar-related Challenges on Striga hermonthica Infested Fields in Western Kenya
}

\author{
Celestine N. Manyasi ${ }^{1}$, Dennis M. W. Ochieno ${ }^{1}$, Francis N. Muyekho ${ }^{2}$, John V. O. Muoma ${ }^{1}$, Mwikali M. \\ Pamela $^{1} \&$ Victoria Naluyange ${ }^{2}$ \\ ${ }^{1}$ Department of Biological Sciences, Masinde Muliro University of Science and Technology (MMUST), P.O. \\ Box 190-50100, Kakamega, Kenya \\ ${ }^{2}$ School of Agriculture, Veterinary Sciences and Technology, Masinde Muliro University of Science and \\ Technology (MMUST), P.O. Box 190-50100, Kakamega, Kenya \\ Correspondence: Celestine N. Manyasi, Department of Biological Sciences, Masinde Muliro University of \\ Science and Technology (MMUST), P.O. Box 190-50100, Kakamega, Kenya. E-mail: \\ manyasicelestine9@gmail.com
}

Received: May 30, 2018

Accepted: June 15, $2018 \quad$ Online Published: July 9, 2018

doi:10.5539/jps.v7n2p41

URL: https://doi.org/10.5539/jps.v7n2p41

\begin{abstract}
Maize production in Western Kenya is constrained by Striga hermonthica and declining soil fertility. Integrated Striga Management (ISM) packages have been proposed. An ISM field experiment assessed combination of 4 maize varieties with 5 levels of soil fertility amendments. Imazapyr Resistant (IR) maize and local yellow seed Shipindi had highest germination percentages of $90 \%$ and $81 \%$ respectively, compared to commercial white seed Duma and local white seed Rachar. Duma had significantly large plants in terms of leave size and plant height; and taking least time to silking and tasseling while producing heaviest cobs and grains per plant. Synthetic fertilizer $(\mathrm{DAP}+\mathrm{CAN})$ was associated with the least germination percentage, but produced the largest plants with many leaves, took the shortest time to silking, and produced highest cob weight and grain weight, with very low $S$. hermonthica infestations regardless of the maize varieties. Cattle manure (CM) and water hyacinth compost containing cattle manure culture (HCM) and Effective Microbes ${ }^{\mathrm{TM}}$ (HEM) had the highest S. hermonthica population per unit area. Maize grown with water hyacinth compost containing Effective Microbes ${ }^{\mathrm{TM}}$ (HEM) positively influenced cob weight than those receiving cattle manure (CM) and the controls; while being associated with the highest numerical increase in grain yield/area. Alternative soil fertility interventions based on these observations are therefore proposed.
\end{abstract}

Keywords: compost, Imazapyr Resistant, Integrated Striga Management, Striga hermonthica

\section{Introduction}

Maize production in Western Kenya is being constrained by the hemi-parasitic weed Striga hermonthica (Oswald, 2005; Avedi et al., 2014). Some reports indicate that local yellow pigmented maize varieties, such as Nyamula and Shipindi, exhibit tolerance to S. hermonthica (Ojiem, Ransom, \& Wakhonya, 1996; Hassan, 1998). This has been raising research interests, especially the relationship between carotenoid expression in yellow maize and the exudation of strigolactones that stimulate the germination of $S$. hermonthica seeds (Matusova et al., 2005; Li, Vallabhaneni, Yu, Rocheford, \& Wurtzel, 2008; Jamil, Charnikhova, Verstappen, \& Bouwmeester, 2010; Jamil, Kanampiu, Karaya, Charnikhova, \& Bouwmeester, 2012). Greater carotenoid expression with concomitant low rate of carotenoid cleavage is suspected to prevent the exudation of carotenoid-derived germination factors for $S$. hermonthica, particularly strigolactones (Matusova et al., 2005; Sun et al., 2008; Floss \& Walter, 2009). Besides, carotenes in yellow maize are important in human nutrition as a source of pro-vitamin A (Hwang et al., 2016).

The innovation of Imazapyr Resistant (IR) maize varieties has offered hope to maize farmers affected by $S$. hermonthica in Western Kenya (Kanampiu et al., 2003; De Groote, Wangare, \& Kanampiu, 2007; Woomer, Mulei, \& Kaleha, 2016). Such maize varieties have altered genes for acetohydroxyacid synthase (AHAS) production (Tan, Evans, Dahmer, Singh, \& Shaner, 2005), making them insensitive to the Imazapyr herbicide (Green, 2007; Menkir, Chikoye, \& Lum, 2010), which instead is lethal to S. hermonthica (Makumbi, Kanampiu, Mugo, \& Karaya, 2015). Unfortunately, IR maize may face challenges performing under conditions of poor soil fertility and acidification that exist in Western Kenya (Vanlauwe et al., 2008). Various organic and synthetic soil 
fertility amendments have been used to enhance plant nutrition while mitigating the effects of $S$. hermonthica (Gacheru \& Rao, 2001; De Groote et al., 2010). Composts have been developed from water hyacinth (Eichhornia crassipes), with potential of promoting bean-Rhizobium symbiosis (Naluyange et al., 2014), as well as enhancing maize production (Osoro et al., 2014). The water hyacinth composts are yet to be tested on Striga-infested maize and other cereal crops.

Unfortunately, no single weed control measure has been successful in controlling S. hermonthica when applied in isolation (Marley, Aba, Shebayan, Musa, \& Sanni, 2004). Integrated Striga Management (ISM) systems are therefore being encouraged to control S. hermonthica in Africa (Schulz, Hussaini, Kling, Berner, \& Ikie, 2003; Avedi et al., 2014). The use of IR maize, or yellow maize that is tolerant to $S$. hermonthica, in combination with water hyacinth composts, could be beneficial for ISM in Western Kenya. Evaluating this ISM approach was the objective of the present study. Our goal is to share information that could create awareness and help mobilize research resources for addressing $S$. hermonthica and soil fertility related problems affecting farmers in Western Kenya.

\section{Materials and Methods}

\subsection{Study Location}

This study was conducted on Striga-infested farmer's field in Busia County, Western Kenya (N 00 41.630', E 034 $12.543^{\prime}$, and 1197 metres a.s.l). This region is among parts of Africa that are heavily infested by $S$. hermonthica (Kilonzi, 2011). Prior to experimentation, soil samples were randomly collected and analyzed for nutrients at the SoilCares Laboratory, Bungoma County. The soils contained nitrogen (1.38 \%), phosphorus (2.8 ppm), potassium $\left(2.1 \mathrm{cmolkg}^{-1}\right)$, magnesium $\left(8.0 \mathrm{cmolkg}^{-1}\right)$, carbon $(11.45 \%)$, calcium $\left(7.5 \mathrm{cmolkg}^{-1}\right)$ and soil $\mathrm{pH}$ of 4.75 .

\subsection{Experimental Design}

The experiment consisted of a $4 \times 5$ factorial treatment design comprising four maize seed types and five types of soil fertility amendments, on a piece of land measuring $32.7 \mathrm{~m} \times 15.9 \mathrm{~m}$. The resulting 20 treatment combinations comprised of plots in the form of $8.7 \mathrm{~m}$ long lines spaced at $0.7 \mathrm{~m}$; each having 30 planting holes spaced at $0.3 \mathrm{~m}$. These were laid out in a completely randomized block design of 3 blocks (replicates). The blocks that measured $13.3 \mathrm{~m} \times 8.7 \mathrm{~m}$ were spaced at $2 \mathrm{~m}$ from each other and $1.3 \mathrm{~m}$ from the field boundary. The experiment was conducted during the long rain season (May to July 2014) and repeated once in time, during the short rains (August to November 2014). Climatic data (rainfall) for this region during the study period can be found in Midega et al. (2015a).

\subsection{Maize and Striga Seeds}

Seeds of Imazapyr Resistant (IR) maize hybrid (FRC 425-IR) (Freshco Seeds, Nairobi, Kenya), pre-treated with the imidazolinone herbicide (De Groote et al., 2007), and those of Duma (SC Duma 43) white seed maize variety (Agri-Seed Company Ltd, Nairobi-Kenya), were purchased from Agrovet shops in Busia town, Kenya. The local yellow seed Shipindi variety and the white seed Rachar variety were purchased from the Busia town market in Kenya. Agronomic performances of these local maize varieties have been reported by Ojiem et al. (1996) and Hassan (1998). S. hermonthica seeds $(0.5 \mathrm{~kg})$ were obtained from Striga harvest stocks at KALRO-Kibos station in Kisumu, and formulated into Striga seed-sand mixture (1:4) (Berner et al., 1997).

\subsection{Soil Fertility Amendments}

Diammonium phosphate (DAP) sowing fertilizer $\left(18 \% \mathrm{~N}\right.$ and $46 \% \mathrm{P}_{2} \mathrm{O}_{5}$ ), and calcium ammonium nitrate (CAN) topdressing fertilizer $(27 \% \mathrm{~N}$ ) (MEA Ltd, Westlands, Nairobi-Kenya), were purchased from Agrovet shops in Busia, Kenya. Water hyacinth compost formulated with Effective Microbes ${ }^{\mathrm{TM}}$ (HEM) or with cattle manure culture (HCM) were obtained from our MMUST-VicRes research facility at Otonglo in Kisumu, after being prepared as described by Naluyange et al. (2014). HEM is fortified with Effective Microbes ${ }^{\mathrm{TM}}$, comprising of photosynthetic bacteria (Rhodopseudomonas palustris), lactic acid bacteria (Lactobacillus plantarum and $L$. casei), yeast (Saccharomyces cerevisae), molasses, and water (EM Technologies Ltd, Embu, Kenya) (Higa \& Parr, 1994; Chandi, 2003). The nutrient composition of the two water hyacinth composts are outlined in Naluyange et al. $(2014,2016)$. Cattle manure (CM) was obtained from stocks locally composted through heaping by farmers.

\subsection{Planting and other Agronomic Practices}

Land was prepared by hand-digging, and planting holes $(\sim 10 \mathrm{~cm}$ diameter and $5 \mathrm{~cm}$ deep) excavated using a hoe. The HCM, HEM and CM composts were applied volumetrically using containers of $150 \mathrm{~mL}$ per hole as per the 
respective treatments and mixed with soil (Naluyange et al., 2014). The water hyacinth composts therefore supplied approximately $0.9 \mathrm{~g} \mathrm{~N}, 0.02 \mathrm{~g} \mathrm{P}$, and $0.99 \mathrm{~g} \mathrm{~N}, 0.03 \mathrm{~g} \mathrm{P}$, for HEM and HCM, respectively (Naluyange et al., 2016). DAP fertilizer was applied at the rate of 2 level teaspoonfuls per planting hole $(\sim 10 \mathrm{~g})$ and mixed with soil; supplying approximately $2.1 \mathrm{~g} \mathrm{~N}$ and $2.3 \mathrm{~g}$ P. One maize seed per hole was planted at a depth of $\sim 3 \mathrm{~cm}$, together with a table spoonful of $S$. hermonthica seed-sand mixture (approx. 1000 seeds) in every planting hole as described by Berner et al., (1997). The DAP treated plants were later top-dressed with CAN once as per the respective treatments at the rate of 2 level teaspoonfuls per maize plant $(\sim 10 \mathrm{~g}), 42$ days after planting, supplying $\sim 1.3 \mathrm{~g} \mathrm{~N}$. Hand weeding was done after every two weeks for all weeds, except $S$. hermonthica (Avedi et al., 2014).

\subsection{Data Collection}

Number of days taken for each maize seed per planting hole to emerge was recorded. The number of emerged maize seedlings out of the total planted seed population per treatment was used to calculate germination percentage. Maize plant growth-related parameters that included plant height, leaf length, leaf width and number of leaves were scored every two weeks until tasseling (10 weeks). Maize plant height from the base of the stem to the apex of the youngest leaf was recorded. The number of open leaves per maize plant, as well as length (base to apex) and width (widest part) of the youngest open leaves were recorded. The number of days from planting to silking, tasseling and physiological maturity of each maize plant was recorded. Cob weights per plant were recorded. Yield-related data that included average grain weight per plant was recorded and expressed as grain weight per unit area.

Number of days from planting to the emergence of the first $S$. hermonthica seedling per host plant was recorded. Population of the parasitic weed per maize plant was recorded daily and used to calculated Striga weed population per unit area (counts per $\mathrm{m}^{2}$ ) (Berner et al., 1997); the number of days to flowering of S. hermonthica was recorded when the first flower appeared per host plant.

\subsection{Statistical Analysis}

Data was analyzed using SAS 9.1 software (SAS Institute Inc.) at $\mathrm{P}<0.05$ significance level. Proc Means was used in generating means and standard errors for maize germination percentage, developmental time, plant size and yield-related parameters, as well as $S$. hermonthica developmental time, population per maize plant and per unit area. The two-week scores for plant height, leaf number and size were averaged. Mean germination percentage for maize was computed from individual percentages of the three treatment replicates per season generated by Proc Freq. S. hermonthica population was expressed as mean counts $/ \mathrm{m}^{2}$ using sums from the three treatment replicates per season, divided by the $6.3 \mathrm{~m}^{2}$ plot size $(0.7 \mathrm{~m} \times 0.3 \mathrm{~m} \times 30$ planting holes $)$. Analysis of variance (ANOVA) between treatments and between seasons was done using Proc GLM with mean separation by Tukey's Studentized Range (HSD) test when there were significant differences.

\section{Results}

\subsection{Germination Percentage and Developmental Time}

Germination percentage was high in IR maize (90\%) and Shipindi $(81 \%)$ compared to Rachar $(73 \%)$ and Duma $(72 \%)(\mathrm{P}<0.05)$. Maize germination percentage was lowest in DAP (68\%) compared to the other treatments $(\mathrm{CM}=77 \%$, Control $=81 \%, \mathrm{HCM}=83 \%, \mathrm{HEM}=84 \%)(\mathrm{P}<0.05)$. Germination percentage did not vary between the two seasons $(\mathrm{P}>0.05)$.

Number of days to maize seed emergence did not vary between the four maize seed varieties and the five soil fertility amendments $(\mathrm{P}>0.05)$ (Table 1$)$. DAP+CAN treated maize plants took the shortest period in days to silking, while the controls took the longest period $(\mathrm{P}<0.0001)$ (Table 1). Duration to silking (days) was shortest in Duma variety and longest in IR maize $(\mathrm{P}<0.0001)$ (Table 1$)$. Total days to maturity did not vary between the maize varieties and the soil fertility amendments $(\mathrm{P}>0.05)($ Table 1$)$.

\subsection{Maize Plant Size and Grain Yields}

DAP+CAN treated maize plants were the largest in terms of height, number and size of leaves; the controls produced the smallest plants $(\mathrm{P}<0.05)$ (Table 1$)$. There was no difference in number of leaves per plant between the four maize varieties $(\mathrm{P}>0.05)$ (Table 1); with the maximum number of leaves at 10 weeks being 17, 16, 17 and 15, for IR maize, local yellow Shipindi, local white Rachar and improved white Duma respectively. Duma maize variety had the largest leaves in terms of length and width, followed by the local white Rachar, while IR maize and the local yellow Shipindi had the smallest leaves $(\mathrm{P}<0.0001)$ (Table 1). The maximum size of leaves (length/width) at 10 weeks being 64/10,69/10.5, 75/9 and 78.3/8.5 for IR maize, local yellow Shipindi, local white Rachar and improved white Duma respectively. IR maize variety had the shortest plants while the other 
three varieties were of similar height $(\mathrm{P}<0.0001)$ (Table 1); with the maximum height at 10 weeks being 164.5, 220, 220 and 180 centimeters, for IR maize, local yellow Shipindi, local white Rachar and Improved white Duma respectively. Plants in the second season were larger than those in the first season in terms of height, number and size of leaves $(\mathrm{P}<0.05)$ (Table 1).

Table 1. Growth and yield of maize varieties grown under different soil fertility amendments on Striga hermonthica infested field in Western Kenya

\begin{tabular}{|c|c|c|c|c|c|c|c|c|c|c|c|c|}
\hline \multirow[t]{2}{*}{$\begin{array}{l}\text { Source of } \\
\text { variation }\end{array}$} & df & $\begin{array}{l}\text { Emergence } \\
\text { duration }\end{array}$ & $\begin{array}{l}\text { Tasseling } \\
\text { duration }\end{array}$ & $\begin{array}{l}\text { Silking } \\
\text { duration }\end{array}$ & $\begin{array}{l}\text { Maturity } \\
\text { duration }\end{array}$ & $\begin{array}{l}\text { Leaf } \\
\text { number }\end{array}$ & $\begin{array}{l}\text { Leaf } \\
\text { width }\end{array}$ & $\begin{array}{l}\text { Leaf } \\
\text { length }\end{array}$ & $\begin{array}{l}\text { Plant } \\
\text { height }\end{array}$ & $\begin{array}{l}\text { Cob weight } \\
\text { per plant }\end{array}$ & $\begin{array}{l}\text { Grain weight } \\
\text { per plant }\end{array}$ & $\begin{array}{l}\text { Grain weight } \\
\text { per unit area }\end{array}$ \\
\hline & & \multicolumn{11}{|l|}{ F values } \\
\hline Season & 1 & 0.80 & 2.19 & 5.71 & na & $33.8^{* * *}$ & $31.15^{* * *}$ & $52.3^{* * *}$ & $201.4^{* * * *}$ & na & na & na \\
\hline Variety & 3 & 1.15 & $14.45^{* * * *}$ & $19.65^{\text {*** }}$ & 0.42 & 0.38 & $9.52^{* * * *}$ & $6.64 * * *$ & $23.37^{* * * *}$ & $7.11^{* * * *}$ & $7.37 * * *$ & 2.57 \\
\hline Fertilizer & 4 & 1.14 & 1.52 & $8.25^{* * * *}$ & 0.34 & $4.44^{* *}$ & 26.23 *** & $24.14^{* * * *}$ & $24.27^{* * * *}$ & $13.39^{* * * *}$ & $4.04 * *$ & 2.28 \\
\hline \multirow[t]{3}{*}{ Fertilizer*Variety } & 12 & 1 & 1.13 & 1.43 & 0.55 & 0.89 & 1.34 & 0.77 & 1.98 & 0.8 & 1.39 & 1.1 \\
\hline & & \multicolumn{11}{|l|}{ Means } \\
\hline & & days & days & days & days & count & centimeters & centimeters & centimeters & grams & grams & Tonnes/ha \\
\hline Overall mean & & $6.57 \pm 0.45$ & $63.09 \pm 0.37$ & $68.81 \pm 0.55$ & $107.22 \pm 0.29$ & $7.27 \pm 0.16$ & $5.16 \pm 0.09$ & $43.43 \pm 0.13$ & $48.22 \pm 0.51$ & $17.11 \pm 0.67$ & $69.75 \pm 3.55$ & $1.37 \pm 0.09$ \\
\hline \multirow[t]{2}{*}{ Seasons } & First & $6.19 \pm 0.86 \mathbf{a}$ & $64.14 \pm 0.34 \mathrm{a}$ & $66.9 \pm 1.06 \mathbf{a}$ & na & $6.59 \pm 1.89 \mathrm{~b}$ & $4.65 \pm 0.15 \mathrm{~b}$ & $40.15 \pm 0.65 \mathrm{~b}$ & $34.79 \pm 1.16 \mathrm{~b}$ & na & na & na \\
\hline & Second & $6.96 \pm 0.08 \mathbf{a}$ & $62.33 \pm 1.17 \mathbf{a}$ & $69.92 \pm 0.65 \mathbf{a}$ & $107.22 \pm 0.29$ & $7.95 \pm 1.14 \mathrm{a}$ & $5.67 \pm 0.11 \mathrm{a}$ & $46.70 \pm 0.63 \mathrm{a}$ & $61.66 \pm 1.50 \mathrm{a}$ & $17.11 \pm 0.67$ & $69.75 \pm 3.54$ & $1.37 \pm 0.08$ \\
\hline \multirow[t]{4}{*}{ Varieties } & ${ }^{\mathrm{a} D u m a}$ & $6.39 \pm 0.08 \mathbf{a}$ & $58.24 \pm 1.01 \mathbf{c}$ & $64.77 \pm 070 \mathbf{c}$ & $106.79 \pm 0.71 \mathbf{a}$ & $7.08 \pm 0.19 \mathbf{a}$ & $5.29 \pm 0.20 \mathbf{a}$ & $43.33 \pm 1.60 \mathbf{a}$ & $53.80 \pm 2.05 \mathrm{a}$ & $20.39 \pm 1.33 \mathbf{a}$ & $86.43 \pm 4.63 \mathbf{a}$ & $1.35 \pm 0.16 \mathbf{a}$ \\
\hline & ${ }^{\mathrm{b}} \mathrm{IR}$ maize & $7.91 \pm 1.71 \mathbf{a}$ & $68.98 \pm 0.87 \mathbf{a}$ & $73.46 \pm 0.80 \mathbf{a}$ & $107.37 \pm 0.31 \mathbf{a}$ & $7.34 \pm 0.43 \mathbf{a}$ & $4.74 \pm 0.16 \mathbf{b c}$ & $37.30 \pm 1.33 \mathbf{c}$ & $41.36 \pm 1.83 \mathbf{b}$ & $15.75 \pm 1.24 \mathbf{b}$ & $44.13 \pm 3.80 \mathbf{c}$ & $1.11 \pm 0.14 \mathbf{a}$ \\
\hline & ${ }^{\mathrm{c}}$ Rachar & $6.08 \pm 0.08 \mathbf{a}$ & $62.42 \pm 0.87 \mathbf{b}$ & $68.59 \pm 0.88 \mathbf{b}$ & $107.49 \pm 0.32 \mathrm{a}$ & $7.01 \pm 0.15 \mathbf{a}$ & $4.88 \pm 0.16 \mathbf{b}$ & $40.73 \pm 1.56$ ab & $52.57 \pm 2.36 \mathbf{a}$ & $16.85 \pm 0.99 \mathbf{b}$ & $82.58 \pm 14.44 \mathbf{a b}$ & $1.37 \pm 0.16 \mathbf{a}$ \\
\hline & ${ }^{\circledR}$ Shipindi & $5.91 \pm 0.07 \mathbf{a}$ & $62.71 \pm 1.79 \mathbf{b}$ & $68.41 \pm 1.51 \mathbf{b}$ & $107.27 \pm 0.24 \mathbf{a}$ & $7.21 \pm 0.17 \mathbf{a}$ & $4.53 \pm 0.18 \mathbf{c}$ & $39.91 \pm 1.71 \mathrm{bc}$ & $56.41 \pm 2.93 \mathbf{a}$ & $15.45 \pm 1.04 \mathbf{b}$ & $65.87 \pm 4.18 \mathbf{b}$ & $1.67 \pm 0.15 \mathrm{a}$ \\
\hline \multirow[t]{5}{*}{ Fertilizers } & ${ }^{\circ} \mathrm{NON}$ & $5.85 \pm 0.09 \mathbf{a}$ & $65.87 \pm 2.60 \mathbf{a}$ & $72.08 \pm 1.30 \mathbf{a}$ & $107.06 \pm 0.25$ & $6.38 \pm 0.10 \mathbf{c}$ & $4.00 \pm 0.08 \mathbf{c}$ & $33.40 \pm 0.85 \mathbf{c}$ & $40.76 \pm 2.17 \mathbf{c}$ & $13.82 \pm 1.0 \mathbf{c}$ & $55.68 \pm 7.45 \mathbf{b}$ & $1.00 \pm 0.11 \mathbf{a}$ \\
\hline & ${ }^{\mathrm{f}} \mathrm{CM}$ & $6.03 \pm 0.08 \mathbf{a}$ & $61.81 \pm 1.03 \mathbf{a}$ & $68.08 \pm 1.00 \mathbf{b}$ & $107.44 \pm 0.28 \mathbf{a}$ & $7.45 \pm 0.52$ ab & $4.78 \pm 0.14 \mathbf{b}$ & $38.94 \pm 1.35 \mathbf{b}$ & $49.66 \pm 2.41 \mathbf{b}$ & $15.63 \pm 0.97 \mathbf{b c}$ & $63.66 \pm 6.10 \mathbf{b}$ & $1.43 \pm 0.20 \mathrm{a}$ \\
\hline & ${ }^{g} \mathrm{DAP}+\mathrm{CAN}$ & $6.20 \pm 0.09 \mathrm{a}$ & $62.28 \pm 1.15 \mathbf{a}$ & $65.18 \pm 1.45 \mathrm{c}$ & $106.77 \pm 0.94 \mathbf{a}$ & $7.89 \pm 0.20 \mathbf{a}$ & $5.67 \pm 0.11 \mathrm{a}$ & $48.19 \pm 1.63 \mathbf{a}$ & $61.87 \pm 3.24 \mathbf{a}$ & $22.82 \pm 1.33 \mathbf{a}$ & $96.83 \pm 17.71 \mathbf{a}$ & $1.30 \pm 0.21 \mathbf{a}$ \\
\hline & "HEM & $6.42 \pm 0.07 \mathbf{a}$ & $62.60 \pm 2.05 \mathrm{a}$ & $68.41 \pm 1.00 \mathbf{b}$ & $107.48 \pm 0.29 \mathbf{a}$ & $7.09 \pm 0.09$ bc & $5.02 \pm 0.23 \mathbf{b}$ & $40.99 \pm 1.12 \mathbf{b}$ & $52.83 \pm 2.13 \mathbf{b}$ & $17.76 \pm 1.11 \mathbf{b}$ & $69.83 \pm 4.69 \mathbf{b}$ & $1.64 \pm 0.17 \mathbf{a}$ \\
\hline & ${ }^{\mathrm{i}} \mathrm{HCM}$ & $8.35 \pm 2.13 \mathbf{a}$ & $62.88 \pm 1.29 \mathbf{a}$ & $70.27 \pm 1.65 \mathbf{a b}$ & $107.38 \pm 0.32 \mathbf{a}$ & $6.99 \pm 0.07 \mathbf{b c}$ & $4.84 \pm 0.12 \mathbf{b}$ & $40.08 \pm 0.91 \mathbf{b}$ & $50.07 \pm 1.77 \mathbf{b}$ & $15.54 \pm 0.95 \mathbf{b c}$ & $62.77 \pm 4.79 \mathbf{b}$ & $1.50 \pm 0.14 \mathbf{a}$ \\
\hline
\end{tabular}

Asterisk indicate the significant effect, ${ }^{* * *} \mathrm{p} \leq 0.001,{ }^{*} \mathrm{p} \leq 0.01,{ }^{*} \mathrm{p} \leq 0.05$. Means with the same letter(s) are not significantly different ( $\mathrm{p}>0.05$ ); those with more than one letter are intermediate. Interactions are considered over main effects where there were significant ${ }^{\mathrm{a}}$ Improved white; ${ }^{\mathrm{b} I m a z a p y r}$ resistant; ${ }^{\mathrm{c}}$ Local white; ${ }^{\mathrm{d}}$ Local yellow; ${ }^{\mathrm{e}} \mathrm{Control} ;{ }^{\mathrm{f}}$ Cattle Manure; ${ }^{\mathrm{g}}$ Diammonium phosphate; ${ }^{\mathrm{h}}$ Hyacinth+effective microbes; ${ }^{\mathrm{i}} \mathrm{Hyacinth}+\mathrm{cattle}$ manure culture; ${ }^{\text {na }}$ parameter scored for only one season

DAP+CAN treated plants produced the heaviest cobs, while the controls had the lowest cob weights $(\mathrm{P}<0.0001)$ (Table 1). DAP+CAN treated maize plants produced the heaviest grain weight per plant compared to plants from the other four soil amendments, which had similar grain weights $(P=0.0077)$ (Table 1). However, these differences in seed weight between soil fertility amendments were not reflected per unit area $(\mathrm{P}>0.05$; Table 1$)$.

Duma maize variety produced the heaviest cobs compared to the cob weights of the remaining three varieties, which were similar $(\mathrm{P}=0.0006)$ (Table 1$)$. Grain weight per plant was highest in Duma variety and lowest in IR maize, while the two local varieties were intermediate $(P=0.0005)$ (Table 1). However, these differences in grain weight between maize varieties did not reflect in weights per unit area $(\mathrm{P}>0.05$; Table 1$)$.

\subsection{Striga Hermonthica Growth and Population}

Per unit area, S. hermonthica population was low on plots that received DAP+CAN and high when the CM, HCM and HEM were applied, regardless of the maize variety $(\mathrm{P}<0.0001)$ (Figure 1). S. hermonthica population per unit area did not vary between seasons $(\mathrm{P}>0.05)$. Duration between planting and Striga emergence $(54.3 \pm$ 1.8 days) did not vary between the treatments $(\mathrm{P}>0.05)$, but was shorter in the first season $(44.1 \pm 1.9$ days $)$ than in the second season $(61.5 \pm 0.9$ days $)(\mathrm{P}<0.0001)$. Duration between Striga emergence and flowering (31.3 \pm 0.7 days) did not vary between treatments and seasons $(\mathrm{P}>0.05)$. 


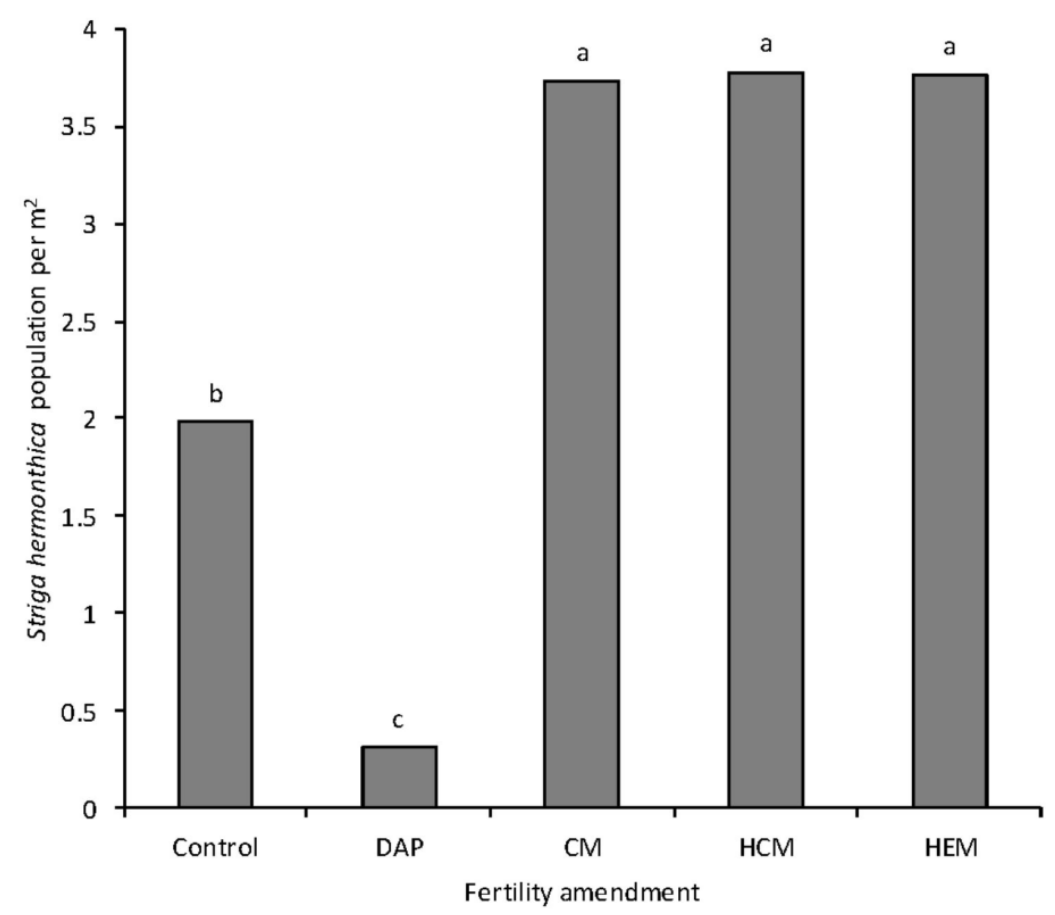

Figure 1. Striga hermonthica populations per unit area on maize varieties under different soil fertility amendments in Western Kenya. Bars with the same letter(s) are not significantly different $(\mathrm{P}>0.05)$. (DAP= diammonium phosphate with calcium ammonium nitrate topdress, DAP+CAN, CM=cattle manure, $\mathrm{HCM}=$ hyacinth +cattle manure culture, HEM= hyacinth +effective microbes)

\section{Discussion}

Maize varieties in the present study yielded quite below their inherent potential. For instance, IR maize only attained 1.1 ton/ha, yet under ideal soil fertility conditions on farmers' fields, this variety has been found to yield 2.5 ton/ha (Kanampiu \& Friesen, 2004). The application of DAP+CAN fertilizers showed potential of improving the size of maize plants. For example, DAP+CAN treated maize plants were $62 \mathrm{~cm}$ tall, had 8 leaves, with leaf size of $48 \mathrm{~cm}$ long and $8 \mathrm{~cm}$ wide; while the controls had the smallest and shortest plants. However, the relevance of the stimulative effect of the DAP+CAN was not reflected in the yield per unit area. The water hyacinth composts and the farmer-produced cattle compost did not offer immediate effect on yield per unit area. Water hyacinth composts have been found to improve maize production (Osoro et al., 2014).

Options for improving maize production on Striga-infested fields in Western Kenya are still being sought (Woomer et al., 2016). Despite the fact that the four maize varieties have their varying advantages, IR maize seeds remain ideal for suppressing S. hermonthica in Western Kenya (Kanampiu et al., 2003; De Groote et al., 2007). This is because the herbicide kills $S$. hermonthica hence reducing the seed bank of this parasitic weed in the soil (Kanampiu \& Friesen, 2004). However, the success of IR maize will greatly depend on the mitigation of the soil fertility problem (Jamil et al., 2012; Larsson, 2012). Alternative soil fertility interventions based on these observations are therefore proposed.

\section{Conclusion}

IR maize seeds remain ideal for suppressing S. hermonthica in Western Kenya. Combined use organic and inorganic fertilizers such as DAP+CAN with water hyacinth compost enhanced with effective microbes (HEM) or cattle manure culture (HCM) could be a viable option for farmers. While DAP+CAN fertilizers offer instant nutrients for maize plant growth, water hyacinth composts on the other hand will improve soil carbon, microbial colonization and diversity, soil fertility and reduce soil acidity in the long run.

\section{Acknowledgements}

This work was conducted under the sponsorship of the Lake Victoria Research (VicRes) Initiative, a regional collaborative research programme of the Inter-University Council for East Africa (IUCEA). Research funds were provided by the Government of Sweden through the Swedish International Development Cooperation Agency 
(SIDA), under the framework of the Lake Victoria Development Partnership (LVDP) Programme. We greatly appreciate support from Mr. Leonard Sadiki Wandera and Agro-Biodiversity Association (ABA) Community-Based Organization for providing land and participating in this work. Thanks to Mr. Edwin Moi Karoney (MMUST) and Fredrick Wandera Majimbo (ABA) for assistance in data collection and processing.

\section{References}

Avedi, E. K., Ochieno, D. M., Ajanga, S., Wanyama, C., Wainwright, H., Elzein, A., \& Beed, F. (2014). Fusarium oxysporum f. sp. strigae strain Foxy 2 did not achieve biological control of Striga hermonthica parasitizing maize in Western Kenya. Biological Control, 77, 7-14. https://doi.org/10.1016/j.biocontrol.2014.05.012

Berner, D. K., Winslow, M. D., Awad, A. E., Cardwell, K. F., Raj, D. M., \& Kim, S. K. (1997). Striga Research Methods. Manual, The Pan-African Striga Control Network (PASCON) and the International Institute of Tropical Agriculture, 13-20.

Chandi, P. N. (2003). EM: A Microbial product for sustainable agriculture. In: Savala, C.E.N., Omare, M.N., Woomer, P.L. (Eds) Organic Resource Management in Kenya: Perspectives and Guidelines. Forum for Organic Resource Management and Agricultural Technologies (FORMAT), Nairobi, Kenya.

De Groote, H., Vanlauwe, B., Rutto, E., Odhiambo, G. D., Kanampiu, F., \& Khan, Z. R. (2010). Economic analysis of different options in integrated pest and soil fertility management in maize systems of Western Kenya. Agricultural Economics, 41(5), 471-482. https://doi.org/10.1111/j.1574-0862.2010.00459.x

De Groote, H., Wangare, L., \& Kanampiu, F. (2007). Evaluating the use of herbicide-coated imidazolinone-resistant (IR) maize seeds to control Striga in farmers' fields in Kenya. Crop Protection, 26(10), 1496-1506. https://doi.org/10.1016/j.cropro.2006.12.013

Floss, D. S., \& Walter, M. H. (2009). Role of carotenoid cleavage dioxygenase 1 (CCD1) in apocarotenoid biogenesis revisited. Plant Signaling \& Behavior, 4(3), 172-175. https://doi.org/10.4161/psb.4.3.7840

Gacheru, E., \& Rao, M. R. (2001). Managing Striga infestation on maize using organic and inorganic nutrient sources in Western Kenya. International Journal of Pest Management, 47(3), 233-239. https://doi.org/10.1080/09670870110044616

Green, J. M. (2007). Review of glyphosate and ALS-inhibiting herbicide crop resistance and resistant weed management. Weed Technology, 21(2), 547-558. https://doi.org/10.1614/WT-06-004.1

Hassan, R. M. (ed) (1998). Maize technology development and transfer: a GIS application for research planning in Kenya. International Maize and Wheat Improvement Center (CIMMYT) and the Kenya Agricultural Research Institute (KARl). CABI International, Wallingford, UK.

Higa, T., \& Parr, J. F. (1994). Beneficial and Effective Microorganisms for a Sustainable Agriculture and Environment. International Nature Farming Research Center Atami, Japan.

Hwang, T., Ndolo, V. U., Katundu, M., Nyirenda, B., Bezner-Kerr, R., Arntfield, S., \& Beta, T. (2016). Provitamin A potential of landrace orange maize variety (Zea mays L.) grown in different geographical locations of central Malawi. Food Chemistry, 196, 1315-1324. https://doi.org/10.1016/j.foodchem.2015.10.067

Jamil, M., Charnikhova, T., Verstappen, F., \& Bouwmeester, H. (2010). Carotenoid inhibitors reduce strigolactone production and Striga hermonthica infection in rice. Archives of Biochemistry and Biophysics, 504(1), 123-131. https://doi.org/10.1016/j.abb.2010.08.005

Jamil, M., Kanampiu, F. K., Karaya, H., Charnikhova, T., \& Bouwmeester, H. J. (2012). Striga hermonthica parasitism in maize in response to N and P fertilisers. Field Crop Research, 134, 1-10. https://doi.org/10.1016/j.fcr.2012.03.015

Kanampiu, F. K., Kabambe, V., Massawe, C., Jasi, L., Friesen, D., Ransom, J. K., \& Gressel, J. (2003). Multi-site, multi-season field tests demonstrate that herbicide seed-coating herbicide-resistance maize controls Striga spp. and increases yields in several African countries. Crop Protection, 22(5), 697-706. https://doi.org/10.1016/S0261-2194(03)00007-3

Kanampiu, F., \& Friesen, D. (2004). Striga weed control with herbicide coated maize seed. CIMMYT, Nairobi, Kenya

Kilonzi, S. M. (2011). Maize production and its implication on food security for small scale farmers in Bukhayo West-Busia Kenya. MSc Thesis, Van Hall Larenstein University of Applied Sciences, The Netherlands. 
Larsson, M. (2012). Soil fertility status and Striga hermonthica infestation relationships due to management practices in Western Kenya. MSc. Thesis, Swedish University of Agricultural Sciences.

Li, F., Vallabhaneni, R., Yu, J., Rocheford, T., \& Wurtzel, E. T. (2008). The maize phytoene synthase gene family: overlapping roles for carotenogenesis in endosperm, photomorphogenesis, and thermal stress tolerance. Plant Physiology, 147(3), 1334-1346. https://doi.org/10.1104/pp.108.122119

Makumbi, D., Kanampiu, F., Mugo, S., \& Karaya, H. (2015). Agronomic performance and genotypexenvironment interaction of herbicide-resistant maize varieties in Eastern Africa. Crop Science, 55(2), 540-555. https://doi.org/10.2135/cropsci2014.08.0593

Marley, P. S., Aba, D. A., Shebayan, J. A. Y., Musa, R., \& Sanni, A. (2004). Integrated management of Striga hermonthica in sorghum using a mycoherbicide and host plant resistance in the Nigerian Sudano-Sahelian savanna. Weed Research, 44(3), 157-162. https://doi.org/10.1111/j.1365-3180.2004.00387.x

Matusova, R., Rani, K., Verstappen, F.W., Franssen, M.C., Beale, M.H., \& Bouwmeester, H. J. (2005). The strigolactone germination stimulants of the plant-parasitic Striga and Orobanche spp. are derived from the carotenoid pathway. Plant Physiology, 139(2), 920-934. https://doi.org/10.1104/pp.105.061382

Menkir, A., Chikoye, D., \& Lum, F. (2010). Incorporating an herbicide resistance gene into tropical maize with inherent polygenic resistance to control Striga hermonthica (Del.) Benth. Plant Breeding, 129(4), 385-392. https://doi.org/10.1111/j.1439-0523.2009.01687.x

Midega, C. A., Bruce, T. J., Pickett, J. A., Pittchar, J. O., Murage, A., \& Khan, Z. R. (2015a). Climate-adapted companion cropping increases agricultural productivity in East Africa. Field Crop Research, 180, 118-125. https://doi.org/10.1016/j.fcr.2015.05.022

Naluyange, V., Ochieno, D. M. W., Wandahwa, P., Odendo, M., Maingi, J. M., Amoding, A., \& Muoma, J. (2016). Belowground Influence of Rhizobium Inoculant and water hyacinth composts on yellow bean infested by Aphis fabae and Colletotrichum lindemuthianum under field Conditions. Journal of Plant Studies, 5(2), 32-46. http://dx.doi.org/10.5539/jps.v5n2p32

Naluyange, V., Ochieno, D.M.W., Maingi, J.M., Ombori, O., Mukaminega, D., Amoding, A., \& Muoma, J.V. (2014). Compatibility of Rhizobium inoculant and water hyacinth compost formulations in Rosecoco bean and consequences on Aphis fabae and Colletotrichum lindemuthianum infestations. Applied Soil Ecology, 76, 68-77. https://doi.org/10.1016/j.apsoil.2013.12.011

Ojiem, J. O., Ransom, J. K., \& Wakhonya, H. W. (1996). Performance of hybrid and local maize with and without fertilizer in Western Kenya. In Maize Productivity Gains Through Research and Technology Dissemination, Proceedings of the 5th Eastern and Southern Africa Regional Maize Conference in Arusha, Tanzania, CIMMYT Maize Program, 149-152.

Osoro, N., Muoma, J. O., Amoding, A., Mukaminega, D., Muthini, M., Ombori, O., \& Maingi, J. M. (2014). Effects of water hyacinth (Eichhornia crassipes [Mart.] Solms) compost on growth and yield parameters of maize (Zea mays). British Journal of Applied Science \& Technology, 4(4), 617.

Oswald, A. (2005). Striga control-technologies and their dissemination. Crop Protection, 24(4), 333-342. https://doi.org/10.1016/j.cropro.2004.09.003

Schulz, S., Hussaini, M. A., Kling, J. G., Berner, D. K., \& Ikie, F. O. (2003). Evaluation of integrated Striga hermonthica control technologies under farmer management. Experimental Agriculture, 39(1), 99-108. https://doi.org/10.1017/S0014479702001084

Sun, Z., Hans, J., Walter, M. H., Matusova, R., Beekwilder, J., Verstappen, F. W. A., Ming, Z., van Echtelt, E., Strack, D., Bisseling, T., \& Bouwmeester, H. J. (2008). Cloning and characterisation of a maize carotenoid cleavage dioxygenase (ZmCCD1) and its involvement in the biosynthesis of apocarotenoids with various roles in mutualistic and parasitic interactions. Planta, 228(5), 789-801. https://doi.org/10.1007/s00425-008-0781-6

Tan, S., Evans, R. R., Dahmer, M. L., Singh, B. K., \& Shaner, D. L. (2005). Imidazolinone - tolerant crops: history, current status and future. Pest management science, 61(3), 246-257. https://doi.org/10.1002/ps.993

Vanlauwe, B., Kanampiu, F., Odhiambo, G. D., De Groote, H., Wadhams, L. J., \& Khan, Z. R. (2008). Integrated management of Striga hermonthica, stemborers, and declining soil fertility in Western Kenya. Field Crops Research, 107(2), 102-115. https://doi.org/10.1016/j.fcr.2008.01.002

Woomer, P. L., Mulei, W., \& Kaleha, C. (2016). Humidtropics innovation platform case study: WeRATE 
operations in West Kenya, In: Dror, I., Cadilhon, J., Schut, M., Misiko, M., Maheshwari, S. (Eds.), Innovation Platforms for Agricultural Development: Evaluating the Mature Iinnovation Platforms landscape. Routledge, New York, 98-116.

\section{Copyrights}

Copyright for this article is retained by the author(s), with first publication rights granted to the journal.

This is an open-access article distributed under the terms and conditions of the Creative Commons Attribution license (http://creativecommons.org/licenses/by/4.0/). 